Скаковська С. C. [1; ORCI ID: 0000-0002-3415-9613], старший викладач,

Клим'юк Ю. Ю. [1; ORCID ID: 0000-0002-2871-0317], здобувач вищої освіти першого (бакалаврського) рівня

${ }^{1}$ Національний університет водного господарства та природокористування, м. Рівне

\title{
РИНОК ПРАЦІ УКРАЇНИ ПІД ЧАС КАРАНТИНУ
}

Статтю присвячено дослідженню структури ринку праці України під час карантинних обмежень, спричинених пандемією Covid-19. Розглядаються тенденції працевлаштування в Україні, трудових еміграцій. Зроблено аналіз розмірів середньої зарплатні робітників та шляхів розвитку ринку праці. Розглянуто динаміку зайнятості та безробіття, трансформації, яких зазнали усі сфери людської діяльності, а також спрогнозовано наслідки подальших дій учасників у цьому середовищі. Досліджено прояви професійно-кваліфікаційного дисбалансу попиту та пропозиції на національному ринку праці. Доведено, що через карантинні обмеження відбувається гальмування в галузях та сферах, що забезпечують працевлаштування та створення робочих місць. Запропоновано, як підвищити зростання економічних показників, стабілізувати ринок праці та забезпечити тенденції стійкості в майбутньому, що задовольнить як роботодавців, так i найманих працівників в Україні.

Ключові слова: пандемія; карантин; ринок праці; карантинні обмеження; працевлаштування; безробіття; робітники; заробітна плата.

Вступ. Впродовж останніх років ринок праці України перебуває у стані трансформації, що супроводжується окремими негативними наслідками, зокрема пов'язаними із зниженням продуктивності праці, погіршенням умов зайнятості, поширенням сегменту нестандартної зайнятості. Значними $є$ прояви професійнокваліфікаційного дисбалансу попиту та пропозиції на національному ринку праці, збільшення навантаження на регіональні ринки праці, зростання рівня безробіття та соціальної напруги в країні. 3 настанням карантину ситуація погіршилась. В Україні загальнонаціональний карантин запровадили 12 березня, приводом до цього стали перші випадки захворювання на Covid-19. Така ситуація похитнула споживчі настрої та майже зупинила декілька галузей: готельний і ресторанний бізнес, роздрібна торгівля, 168 
авіаперевезення. Промисловість постраждала чи не найбільше; більшість секторів досягли максимального спаду у квітні та лише трохи змогли реабілітуватися у травні. Оскільки постраждали галузі, що надавали найбільшу частку робочих місць, значно збільшилось число безробітних. Загалом епідемія коронавірусу вплинула на стан зайнятості мільйонів людей у всьому світі.

Аналіз останніх досліджень і публікацій. Різноманітні аспекти розвитку ринку праці України, динаміку зайнятості та безробіття, вплив Коронавірусних обмежень на умови праці у своїх дослідженнях розглянули: Йолана Каменчук, Дарія Михайлишина, Тимофій Брік, Максим Обрізан, Микола Кондратенко, Юлія Горбань, Олександр Голубов, Вікторія Хожаінова.

О. Голубов, В. Хожаінова, Ю. Горбань та Д. Михайлишина заявили про стрімке поглиблення безробіття, загалом кількість безробітних зросла майже на 50\%, з них 17\% громадян опинилися у стані «прихованого безробіття». 3 початку запровадження обмежувальних карантинних заходів, стали безробітними близько 156 тисяч громадян. Кількість вакансій на початку травня також значно зменшилась - на $60 \%$.

Більше того, великі галузі та підприємства української економіки борються з проблемою прихованого безробіття. I ось, у червні ЗМІ повідомляли, що з 1 липня АТ «Укрзалізниця» переведе на чотириденний робочий тиждень працівників штаб-квартири компанії, регіональних офісів та дочірніх підприємств, а також інженерно-технічний персонал. Хоча запровадження неповного робочого тижня не стосуватиметься працівників, які виконують: ремонтні роботи (реконструкція та ремонт колій, стрілочних переводів, штучних конструкцій); ремонт, обслуговування та налагодження основного технологічного обладнання; прямий перевезення вантажів та людей та їх поводження. Слід також зазначити, що «наприкінці серпня компанія повернеться до перегляду цього рішення». Президент правління Укрзалізниці І. Юрик наголошував, що «повернення до повного робочого тижня буде залежати від відновлення економіки України та обсягу вантажних перевезень залізницею».

Цікаві факти з дослідів Т. Бріка та М. Обрізана свідчать про те, що:

- особи зайняті у сферах досліджень, програмування та IT, реклами та засобів масової інформації, а також у фінансовій, банківській та юридичних сферах мають кращу фінансову ситуацію; 
- висококваліфіковані фахівці отримали більший рівень значущості та вищі шанси працювати віддалено;

- перспективи працевлаштування і надалі залишатимуться високими для лікарів, адвокатів, менеджерів, військовослужбовців, поліцейських, працівників сфери державного управління.

Отже, зросла кількість людей, яких скоротили і які змушені шукати роботу. Відповідно вони досить активно розглядають пропозицію і згодні на якісь речі, які $є$ для них оптимальними в режимі «тут і зараз». Починає розвиватися «сірий» ринок - той, де щось врахувати взагалі нереально, оскільки зайнятість $€$ тіньовою, в якій важко щось проконтролювати чи довести.

Постановка завдання. Основним завданням $\epsilon$ проведення всебічного та розширеного аналізу всіх факторів, що стосуються функціонування ринку праці, та прогнозування наслідків, що буде дуже корисним для коригування подальших дій учасників у цьому середовищі. Аналіз ринку праці виявляє той факт, що він останніми роками перебуває у стані перехідного періоду. Ці зміни супроводжуються негативними наслідками, такими як зниження продуктивності праці, погіршення умов зайнятості, показники професійного дисбалансу між попитом та пропозицією на національному ринку праці, поширення нестандартної зайнятості та міграція робочої сили.

За нинішніх обставин основними факторами, що впливають на процеси, які відбуваються на ринку праці, є наступні:

- структурна перебудова економіки, особливо основний розвиток галузі послуг;

- прискорення економічного зростання;

- формування підприємницького потенціалу;

- технічний прогрес, соціальна інформація;

- регулювання розвитку зайнятості.

Проте, 3 приходом коронавірусу до України, абсолютно усі сфери людської діяльності зазнали трансформації. Загалом, через карантинні обмеження відбулось гальмування у галузях та сферах, що забезпечують працевлаштування та створення робочих місць. У цьому випадку необхідно з'ясувати, що змінилося і як вирішити проблеми, які виникли на ринку праці.

Результати досліджень. SARS-COV-2 поширюється переважно повітряно-крапельним шляхом між людьми, які знаходяться в тісному контакті між собою (приблизно на відстані 1 м). Коли інфікована людина кашляє, чхає або розмовляє, краплі слини або виділення з носа можуть потрапити на обличчя (навколо рота, носа 170 
або очей) людей поблизу і звідти проникнути в дихальні шляхи. Ви також можете заразитися, торкаючись поверхонь, заражених вірусом, а потім свого обличчя.

У людей, інфікованих SARS-COV-2, симптоми захворювання зазвичай проявляються через 5-6 днів після контакту з вірусом. Інкубаційний період становить 1-14 днів, що означає, що в деяких випадках симптоми з'являються на наступний день після зараження, а в інших випадках це майже 2 тижні. В даний час Генеральне управління охорони здоров'я та карантину рекомендує ізоляційний період 14 днів. Важливо пам'ятати, що COVID-19 також може протікати безсимптомно. Отже, Covid-19, характерні симптоми захворювання: лихоманка, сухий кашель, задишка, характерна сильна втома, біль у м'язах, біль у горлі, головний біль, втрата або порушення смаку та /або запаху (характерний симптом),

Симптоми, які трапляються рідше:

- діарея;

- кон'юнктивіт;

- шкірний висип або зміна кольору пальців рук і ніг.

Симптоми, які можуть проявитися при тяжкому перебігу COVID-19:

- утруднене дихання або задишка;

- біль у грудях або скутість;

- порушення мови або моторики.

Частота окремих симптомів варіюється залежно від регіону та вікової групи. У більш важких випадках інфекція може спричинити двобічну інтерстиціальну пневмонію, важку гостру дихальну недостатність, поліорганну недостатність, сепсис, септичний шок та навіть смерть.

У період дії карантину (з 12 березня до 20 листопада 2020 року) зареєстровано 641 тис. безробітних, найбільше втратили свої робочі місця у квітні - 149 тис. осіб та в травні - 97 тис. осіб.

Найбільш популярні професії на ринку праці України у 2020 році:

- кваліфіковані робітники з інструментом (швачка, слюсарремонтник, електромонтер, електрогазозварник, робітник 3 комплексного обслуговування й ремонту, монтер колії, маляр, слюсар аварійних робіт, слюсар-сантехнік, пекар);

- робітники з обслуговування, експлуатації устаткування та машин (оператор, машиніст котельної, водій, водій навантажувача, тракторист, оператор заправних станцій, дорожній робітник, машиніст екскаватора, токар, фрезерувальник); 
- професіонали (інспектор, інженер, провізор, лікар, вчитель, вихователь, керівник музичний, психолог, економіст);

- працівники сфери торгівлі та послуг (продавець, кухар, перукар, охоронник, поліцейський, офіціант, бармен, помічник вихователя);

- некваліфіковані працівники (підсобний робітник, сторож, вантажник, укладальник-пакувальник, кухонний робітник, двірник, комірник, робітник 3 комплексного прибирання будинків, прибиральник службових приміщень);

- фахівці (сестра медична, фармацевт, електрик, майстер виробничого навчання, технік, механік, електромеханік, фельдшер, бухгалтер);

- керівники (менеджер, майстер, головний бухгалтер, завідувач господарства, начальник відділу поштового зв'язку, менеджер із збуту).

3 них зареєстровано безробітними станом на 1 грудня 2020 року: 63,3 тис. осіб службовців та керівників, 41,6 тис. осіб професіоналів, 48 тис. осіб фахівців, 25.8 тис. осіб технічних службовців, 74,3 тис. осіб працівників сфери торгівлі та послуг, 13,5 тис. осіб кваліфікованих робітників сільського господарства, 38,5 тис. осіб кваліфікованих робітників з інструментом, 55,7 тис. осіб робітників 3 обслуговування та експлуатації устаткування, та 48,1 тис. осіб робітників найпростіших професій (рисунок).

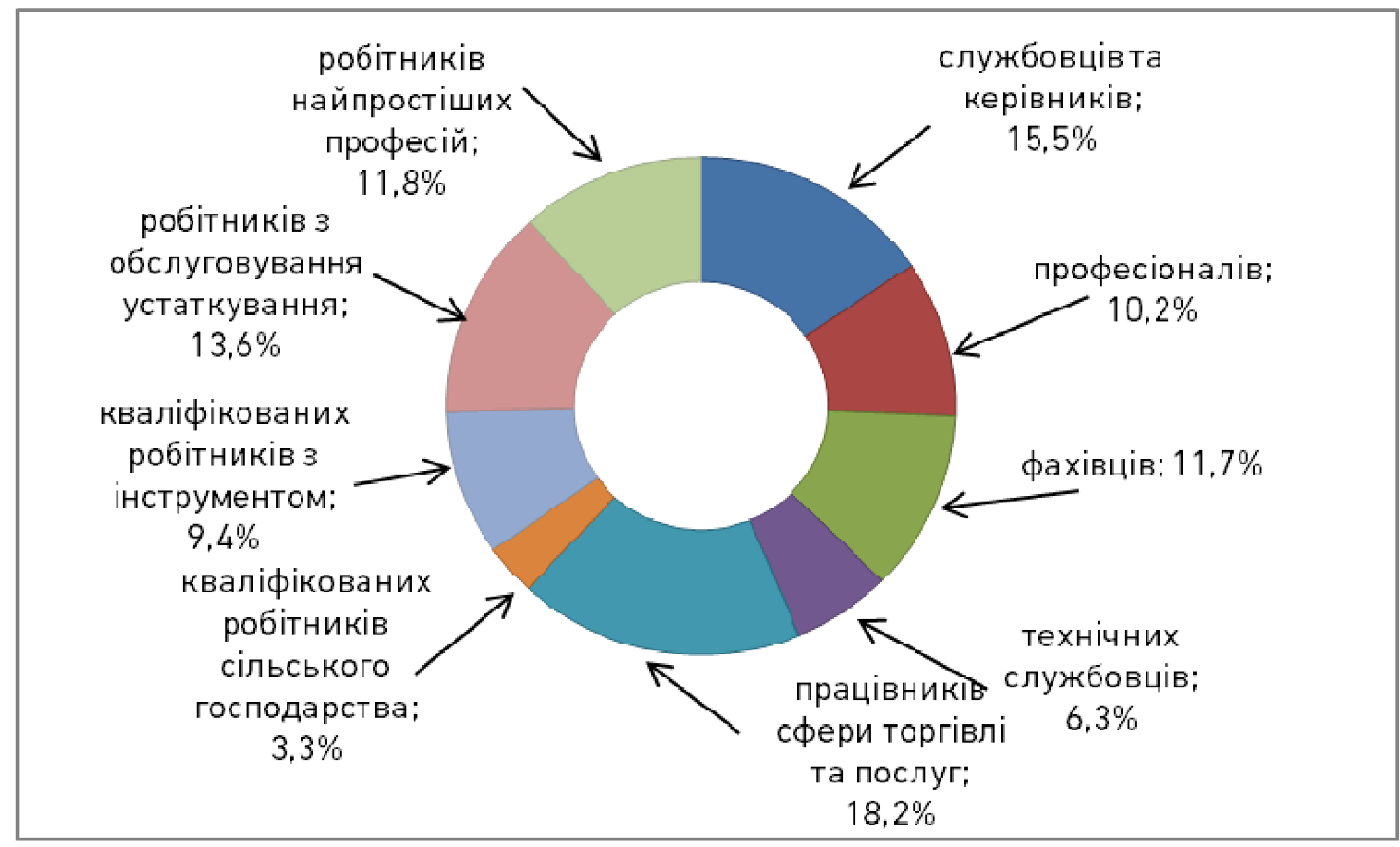

Рисунок

Джерело: сформовано автором 
Скорочення обсягів та рівня зайнятості відбулося як у жінок на 247 тис. осіб, так і у чоловіків - на 183 тис. осіб, у селах - на 140 тис. осіб, та у містах - на 290 тис. осіб. На період січня-листопада 2020 року роботодавці отримали інформацію про заплановане масове вивільнення 252 тис. працівників, що на 40\% (73 тис.) більше ніж минулого року. Найбільш масові скорочення відбулися серед працівників державного управління та оборони, сфери охорони здоров'я та надання соціальної допомоги.

У жовтні 2020 року середній розмір заробітної плати в Україні становив 12,2 тис. гривень, це на $14 \%$ більше ніж у жовтні 2019 року. Найвищу заробітну плату отримують працівники сфери авіації 23 тис. гривень, у фінансовій та страховій діяльності - 20,5 тис. гривень; найнижчу - працівники поштової та кур'єрської діяльності та у тимчасовому розміщенні та організації харчування - 6-7 тис. гривень.

Під час пандемії попит на доставку їжі підвищився на 25\%, проте не всі заклади громадського харчування змогли вистояти в карантинних умовах, тому багато з них були змушені зачинитися, деякі - скасувати заплановане відкриття. Ці факти виступають показником того, що часто малий та середній бізнес не в змозі «залишатися на плаву» в умовах карантину, та створювати задовільну кількість робочих місць.

Враховуючи скорочення цього року кількості робітниківмігрантів з України, до кінця цього року слід очікувати зменшення обсягу коштів, які будуть перераховані в Україну. Зменшення обсягів приватних трансфертів в Україну з-за кордону в 2020 році відображає реальний процес зменшення доходів населення нашої країни в цілому. Так, згідно з оцінкою експертів НБУ, представленою в «Звіті про стабільність фінансової системи. Червень 2020», у 2020 році трирічна тенденція зростання доходів припиниться.

Побоювання щодо другої хвилі пандемії коронавірусу стримуватимуть роботу. Підвищення заробітної плати після скасування карантинних обмежень малоймовірне. Ще до кризи різке зростання витрат на робочу силу перешкоджало зростанню прибутковості підприємств. Доходи фізичних осіб-підприємців, на які наразі припадає майже чверть наявного доходу населення, також скоротяться - цей сегмент найбільше постраждав від карантинних обмежень. Так, за інформацією Info Sapiens, у квітні респонденти найчастіше повідомляли про погіршення самопочуття. Це число впало до рівня 2016 року, коли економіка лише починала відновлюватися від попередньої кризи. У травні через зменшення карантинних обмежень фінансовий стан населення дещо покращився, але залишається нижче рівня на початку цього року. 
Проте водночас відтік робочої сили загрожує економічному розвитку, а українські підприємці дедалі частіше скаржаться на брак кваліфікованих кадрів, спричинений від"їдом українців до Польщі та переважно країн Європи. Найбільше від трудових еміграцій страждають такі галузі України, як промисловість, будівництво, сільське господарство, транспорт та зв'язок.

Для вирішення проблеми. Найважливішою проблемою, яку необхідно вирішити першочергово, є прогресивна захворюваність населення коронавірусом. Для того, щоб вирішити цю проблему, необхідно провести масові вакцинації. Це дозволить сповільнити темпи поширення хвороби, а в майбутньому стабілізувати показники захворюваності в Україні та усьому світі, взяти хворобу під контроль.

Потрібно «перезавантажити» та відновити український ринок праці. Важливо підсилити фінансову підтримку державних підприємств, особливо у період адаптації економіки до нових умов. Це сприятиме створенню достатньої кількості робочих місць. Необхідною $€$ підтримка малих та середніх підприємств та підвищення інтересу громадян до зайнятості.

Варто не лише розвивати установи, що забезпечують робочі місця, а й підвищувати обізнаність та вдосконалювати кваліфікацію робітників, створюючи попит на досвідчених фахівців. Здатність позитивно впливати на це включатиме створення програм навчання на виробництві, різноманітних курсів та тренінгів. Якщо ці умови будуть дотримані, відбудеться не лише зростання економічних показників, стабілізація ринку праці та тенденція процвітання в майбутньому, що задовольнить як роботодавців, так і найманих працівників в Україні.

1. Дослідження громадської організації «Центру прикладних досліджень» представництва фонду Конрада Аденауера в Україні. URL: https://www.kas.de/documents/270026/ (дата звернення: 03.02.2021). 2. Звіт державної служби зайнятості про стан ринку праці України за період карантину. URL: https://www.kmu.gov.ua/news/derzhsluzhba-zajnyatosti-pro-rinok-praci-vukrayini-za-period-karantinu (дата звернення: 03.02.2021). 3. Доповідна аналітична записка «Освітньо-професійна структура ринку праці: сучасні виклики та загрози». URL: $\quad$ https://robotodavets.org.ua/2018/12/12/yak-zminyvsya-rynok-pratsi-vukrayini.html (дата звернення: 03.02.2021). 4. Вікторія Хожаїнова. Хто потрібен на ринку праці в Україні i на що чекати після карантину. URL: https://suspilne.media/28250-hto-potriben-na-rinku-praci-v-ukraini-nazvano-sistsfer/ (дата звернення: 03.02.2021). 5. Центр економічної стратегії, дослідження Дарії Михайлишиної: «якою була ситуація на инку праці та чи відбувається відновлення?» URL: https://ces.org.ua/labor-market-during-quarantine-ukraine/ (дата звернення: 03.02.2021). 6. Сайт dw.com Люди на експорт. Як трудова міграція впливає на українську економіку. URL: https://www.google.com/amp/s/amp.dw.com/uk (дата звернення: 03.02.2021). 7. Інформація про коронавірус / Міністерство охорони здоров'я України. URL: 
https://moz.gov.ua/koronavirus-2019-ncov (дата звернення: 03.02.2021). 8. Офіційний інформаційний портал Кабінету Міністрів України. URL: https://covid19.gov.ua/ (дата звернення: 03.02.2021). 9. Симптоми коронавірусу URL: https://medicover.ua/koronavirus/symptomy.html (дата звернення: 03.02.2021).

\section{REFERENCES:}

1. Doslidzhennia hromadskoi orhanizatsii «Tsentru prykladnykh doslidzhen» predstavnytstva fondu Konrada Adenauera $v$ Ukraini. URL: https://www.kas.de/documents/270026/ (data zvernennia: 03.02.2021). 2. Zvit derzhavnoi sluzhby zainiatosti pro stan rynku pratsi Ukrainy za period karantynu. URL: https://www.kmu.gov.ua/news/derzhsluzhba-zajnyatosti-pro-rinok-praci-v-ukrayiniza-period-karantinu (data zvernennia: 03.02.2021). 3. Dopovidna analitychna zapyska «Osvitno-profesiina struktura rynku pratsi: suchasni vyklyky ta zahrozy». URL: https://robotodavets.org.ua/2018/12/12/yak-zminyvsya-rynok-pratsi-v-ukrayini.html (data zvernennia: 03.02.2021). 4. Viktoriia Khozhainova. Khto potriben na rynku pratsi v Ukraini i na shcho chekaty pislia karantynu. URL: https://suspilne.media/28250-htopotriben-na-rinku-praci-v-ukraini-nazvano-sist-sfer/ (data zvernennia: 03.02.2021). 5. Tsentr ekonomichnoi stratehii, doslidzhennia Darii Mykhailyshynoi: «lakoiu bula sytuatsiia na ynku pratsi ta chy vidbuvaietsia vidnovlennia?» URL: https://ces.org.ua/labor-market-during-quarantine-ukraine/ (data zvernennia: 03.02.2021). 6. Sait dw.com Liudy na eksport. Yak trudova mihratsiia vplyvaie na ukrainsku ekonomiku. URL: https://www.google.com/amp/s/amp.dw.com/uk (data zvernennia: 03.02.2021). 7. Informatsiia pro koronavirus / Ministerstvo okhorony zdorovia Ukrainy. URL: https://moz.gov.ua/koronavirus-2019-ncov (data zvernennia: 03.02.2021). 8. Ofitsiinyi informatsiinyi portal Kabinetu Ministriv Ukrainy. URL: https://covid19.gov.ua/ (data zvernennia: 03.02.2021). 9. Symptomy koronavirusu. URL: https://medicover.ua/koronavirus/symptomy.html (data zvernennia: 03.02.2021).

Skakovska S. S. ${ }^{[1 ; 0 R C I ~ I D: ~ 0000-0002-3415-9613], ~}$ Senior Lecturer,

Klymiuk Yu. Yu. [1; ORCID ID: 0000-0002-2871-0317], Senior Student

${ }^{1}$ National University of Water and Environmental Engineering, Rivne

\section{LABOUR MARKET OF UKRAINE DURING QUARANTINE}

The article is dedicated to the structural study of the labour market in Ukraine during the quarantine period caused by the Covid-19 pandemic. This article explores the trends of employment in Ukraine, which is currently in a state of fundamental changes in all processes that occur in society, and are accompanied by certain negative consequences that are reflected in all sectors, and enterprises of the Ukrainian economy associated with a decrease in labour productivity, deterioration of employment conditions, and 
the spread of the segment of non-standard employment. Also, the article sharply raised a question of labour emigration, in particular, this applies to such sectors of Ukraine as industry, construction, agriculture, transport and communications. The situation caused by the COVID-19 pandemic has very sharply influenced the outflow of labour and threatens economic growth, while Ukrainian entrepreneurs are increasingly complaining about the lack of qualified personnel caused by the departure of Ukrainians to European countries. Analyzed the size of the average salaries of employees, and ways to improve and develop the labour market. Characterized what kind of transformation has taken place in all spheres of human activity, what are the manifestations of the professional and qualification imbalance on a supply and demand at the national labour market. The article highlighted working specialities that remain relevant and have not felt the significant impact of quarantine restrictions. How over quarantine restrictions slowed down industries and spheres that affect job creation. The article proposes how to increase economic indicators level, stabilize the labour market and ensure future tenacity trends for both employees, employers and hired workers satisfaction in Ukraine. Given that the coronavirus epidemic has affected the condition of millions of people around the world, society needs to make a comprehensive and expanded analysis of all factors that relate to consequences prediction, which will be very useful for correcting the longrange actions of participants in this environment.

Keywords: pandemic; quarantine; labour market; quarantine restrictions; employment; unemployment; workers; salaries.

$$
\begin{array}{r}
\text { Скаковская С. С. [1; 0RCI ID: 0000-0002-3415-9613], } \\
\text { Старший преподаватель, } \\
\text { Клымюк Ю. Ю. }{ }^{[1 ; \text { ORCID ID: 0000-0002-2871-0317], }}, \\
\text { соискатель высшего образования первого (бакалаврского) } \\
\text { уровня }
\end{array}
$$

${ }^{1}$ Национальный университет водного хозяйства и природопользования, г. Ровно

\section{РЫНОК ТРУДА УКРАИНЫ ВО ВРЕМЯ КАРАНТИНА}

Статья посвящена исследованию структуры рынка труда Украины во время карантина, вызванного пандемией Covid-19. Рассматриваются тенденции трудоустройства в Украине и трудовых эмиграций. Сделан анализ размеров средней зарплаты рабочих и путей развития рынка труда. Рассмотрена динамика занятости и безработицы, трансформации, которые понесли все сферы человеческой деятельности, а также спрогнозированы последствия дальнейших действий участников в этой среде. Исследованы проявления профессионально-квалификационного 
дисбаланса спроса и предложения на национальном рынке труда. Доказано, что из-за карантина происходит торможение в отраслях и сферах, обеспечивающих трудоустройство и создание рабочих мест. Предложено, как повысить рост экономических показателей, стабилизировать рынок труда и обеспечить тенденции устойчивости в будущем, удовлетворяющее как работодателей, так и наемных работников в Украине.

Ключевые слова: пандемия; карантин; рынок труда; карантинные ограничения; трудоустройство; безработица; рабочие; заработная плата.

Отримано: 05 лютого 2021 р. Прорецензовано: 10 лютого 2021 р. Прийнято до друку: 26 березня 2021 р. 